\title{
2 次核の発生と成長過程について
}

\author{
村田芳治・山川浩 \\ 奥 本茂・川上泰 伸 \\ 今 井隆之
}

東京農工大学工学部 化学工学科 ${ }^{\dagger}$

硫酸銅 5 水塩とカリ明ばん 12 水塩を用い，㩭汼槽で 2 次核を発生させ，その粒子密度と粒径分 布の経時変化をコールターカウンターで追跡し, 次のような結果を得た.

1）過飽和溶液でも，経過時間の初期の段階で粒子密度が減少することを認めた。 この減少率 は過飽和度に相関することを認めた。

2) 两系とも累積曲線の形は経過時間とともに変化した. $\mathrm{CuSO}_{4} \cdot 5 \mathrm{H}_{2} \mathrm{O}$ の場合はその変化が平均 值より小さい成長速度を持つ粒子の存在に起因し, $\mathrm{KAl}\left(\mathrm{SO}_{4}\right)_{2} \cdot 12 \mathrm{H}_{2} \mathrm{O}$ の場合は早い成長速度を持つ 粒子の存在に起因した。

3） 2 次核発生のための最小粒径の存在を確認した。

\section{緒言}

2 次核化現象については，その発生機構の本質的な研 究から 2 次核発生速度の定量的評価の研究にいたるま で, 幅広く研究が行われてきた。これらに関しては豊 倉ら ${ }^{3)}$ の解説がある. 最近, Larson $ら^{2)}$, Garside $ら^{1)}$

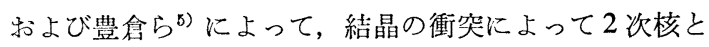
なる微小結晶片が飛散される所謂ミクロアトリション機 構について検討が行われた.

本研究は親結晶から一定量の 2 次核を発生させた後, 親結晶を除き，発生した 2 次核を種晶とし，これを種々 の条件で成長させ，その粒径分布の経時変化を追跡し て, 2 次核の発生現象を考察するとともに，2次核発生 のための種晶の最小粒径について検討した。

\section{1. 実 験 方 法}

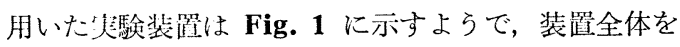
$25 \pm 0.5^{\circ} \mathrm{C}$ に調節された恒温室に設㯰した。結晶槽はす ベてィタアクリル樹脂製で，内径 $30 \mathrm{~cm}$ ，穓找羽根は直 径 $15 \mathrm{~cm}$ の 6 枚羽根タービンを用いた.

コールターカウンターのアパチヤー管を Fig. 1 のよ うに改造して, 結晶槽内に挿入し，母液をサンプリング することなく直接測定できるようにした。

$26.5^{\circ} \mathrm{C}$ の飽和溶液浪整された日液を，あらかじめ $40^{\circ} \mathrm{C}$ で覺抖しながら 2 時間保持した後, $21.5^{\circ} \mathrm{C}$ に調 節された恒温水槽から冷却水を冷却器に通じて, 約 $0.2^{\circ} \mathrm{C} /$ 分の冷却速度になるよう調節しながら過飽和領域

+ 广184 小金井市中町 $2-24-16$

* 以下特にことわらない限り結晶水は少略して記す.
にする．ここで 10２0 mm の大きさの結晶を懸垂して 2 次核を発生させる. 発生を視認したら直ちに親結晶を 取り出し, 冷却水を恒温水槽 II (過飽和温度に近い温度 で一定に維持される）に切り換えるとともにヒーターに よって1.5〜 2 分間で実験条件の温度に調節する.この 間の温度変化の様子を Fig. 2 に示した. 溶液温度が実 験条件の過飽和温度に達し一定になってから粒径分布の 測定を開始し, 最大径が $250 \mu \mathrm{m}$ を超えるまで継続し た.な打 2 次核の発生数は過冷却度で調節した。

コールターカウンターの測定原理は細孔を粒子が通過 する際の電気抵抗の变化をとら兄て粒子数と体積を求め るものであるが，電気的ノイズに非常に敏感であるた め，本研究ではアースを完全にしかつ装置全体を Fig.1 に示すように金龬でンールドしたボックス内に設置し た.

用いた系は硫酸銅 5 水壏*とカリ明ばん 12 水塩*で, 飽和温度を $26.5^{\circ} \mathrm{C}$ 一定とし, Table 1 に示すような実 験条件で検討した。

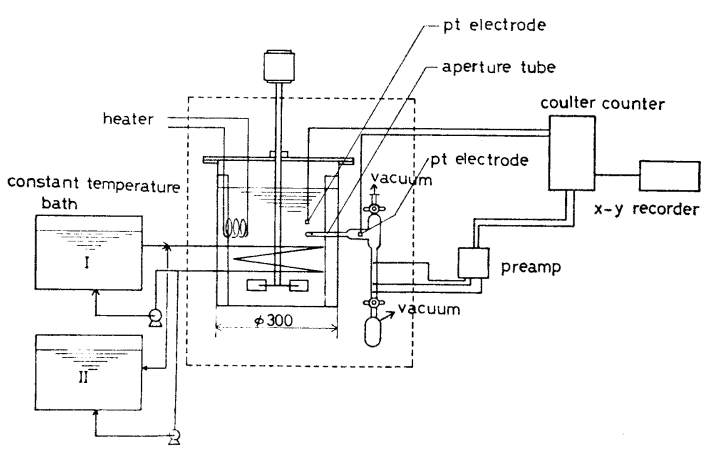

Fig. 1 Schematic diagram of experimental appratus 


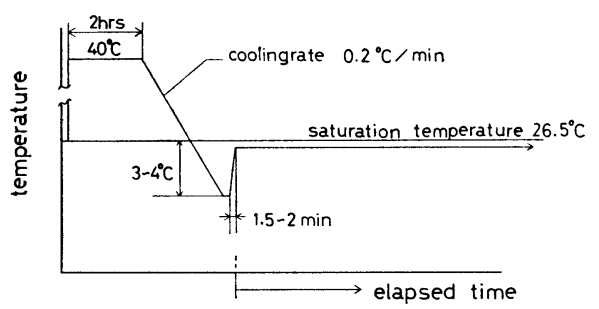

Fig. 2 Controlling diagram of experimental temperature

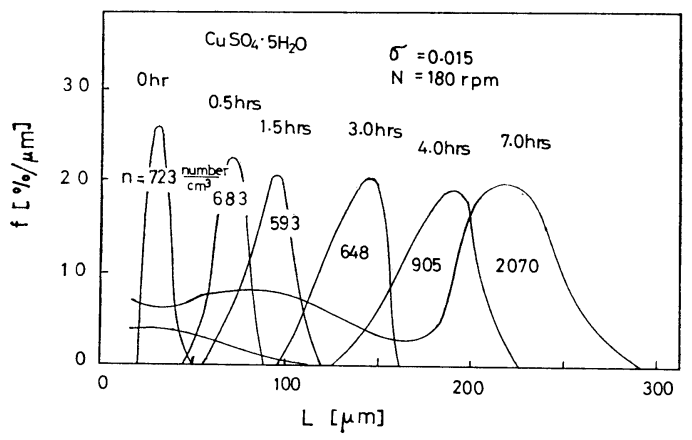

Fig. 3 Variation of number frequency distribution with elapsed time for $\mathrm{CuSO}_{4} 5 \mathrm{H}_{2} \mathrm{O}$

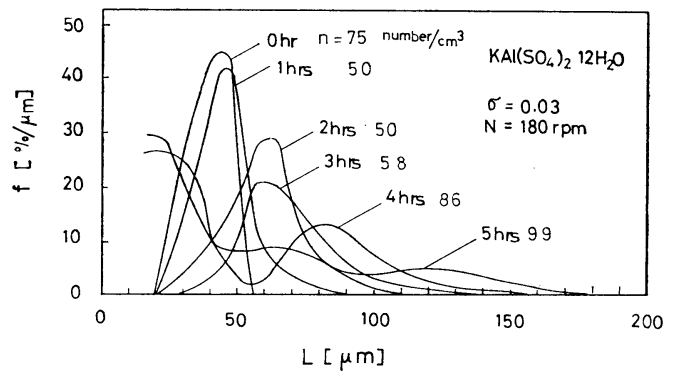

Fig. 4 Variation of number frequency distibution with elapsed time for $\mathrm{KAl}\left(\mathrm{SO}_{4}\right)_{2} 12 \mathrm{H}_{2} \mathrm{O}$

Table 1 Experimental conditions

\begin{tabular}{lccc}
\multicolumn{1}{c}{ System } & $\begin{array}{c}\text { Relative } \\
\text { supersatura- } \\
\text { tion } \sigma \\
{[-]}\end{array}$ & $\begin{array}{c}\text { Suspension } \\
\text { density } n \\
\text { at end point } \\
\text { [number/cm }\end{array}$ & $\begin{array}{c}\text { Impeller } \\
\text { speed } N\end{array}$ \\
\hline [rpm]
\end{tabular}

\section{2. 実 験 結 果}

\section{$2 \cdot 1$ 粒子密度の経時変化}

コールターカウンターの信頼できる測定範囲はアパチ ャ一管の孔径の 0.2 40 パーセントで，乙たがって細孔 径 $560 \mu \mathrm{m}$ の管を用いる場合は 12 224 $\mu \mathrm{m}$ が高精度で测 定できる範囲である. $12 \mu \mathrm{m}$ 以下の粒子群を測定するた めに小孔径の管を用いたが結晶によって細孔がしばしば 閉塞し円滑な测定ができなかったこと㧍よび本研究の目 的は成長しつつある粒子群の粒子密度と粒径分布の経時 変化を追跡することにあるので，ある测定時で計測され

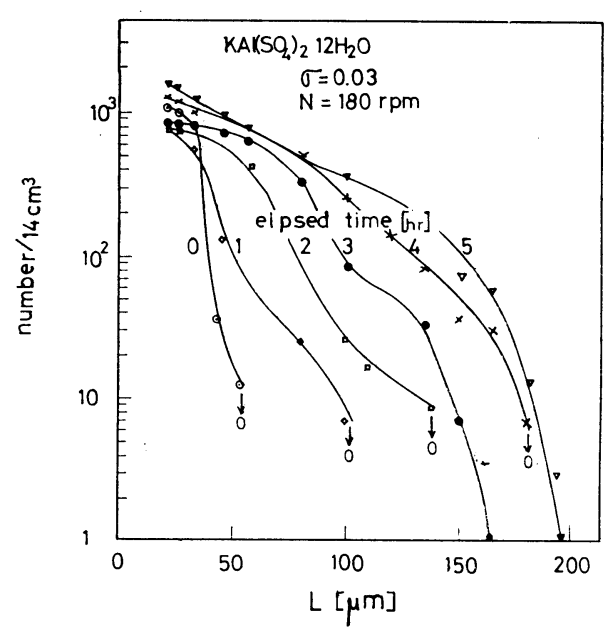

Fig. 5 Variation of size distribution with elapsed time for $\mathrm{KAl}\left(\mathrm{SO}_{4}\right)_{2} 12 \mathrm{H}_{2} \mathrm{O}$

なかった $19 \mu \mathrm{m}$ 以下の粒子も次の测定時では部测可能 な範囲に成長してくることから，アハチナ一管は主こし て細孔径 $560 \mu \mathrm{m}$ のものを用い, 19 凡m 以下の粘子の 测定をカットして垁験した.

得られた結果の一例を Figs. 3 と 4 に示す. 汹で粒 子密度は一時減少し，2次核の発生とももに序び增加す る傾向が見られる、すなわら硫酸銅の埸合は测定開始時 の粒子密度は 723 個 $/ \mathrm{cm}^{3}$ であったが 1.6 時問後には 596 個 $/ \mathrm{cm}^{3}$ になり，3 時間後には 648 個 $/ \mathrm{cm}^{3}$ になる. その後は 2 次核の発生が盛んになり, 経過時間之ともに 急に増加するようになる。この傾向はFig. 4 のカリ明 ばんの場合では一尿顕著で特に実騟初期与なおち粘径が 20〜50 $\mu \mathrm{m}$ での変化が著しいことがわかる.

粒子密度の変化の状況は Fig. 5 の累程曲線で䘮す之 さらに明暸となる。図は $14 \mathrm{~cm}^{3}$ 中の粘子数で示したが， $50 \mu \mathrm{m}$ 以下の粒子数の変化が著しいこょが敞みえれる. な扔弾中で矢印で0と示したのは，これより大きい粒子 が計测されなかったことを示す。

このような粒径の小さい籁囲での粕子数の減少現象は 行ったすべての実験で確認された。いま测定開始時の粒 子密度を $n_{0}$ とし, 計测された最小粒子密度を $n_{\min }$ と すると粒子の残留率 $n_{\min } / n_{0}$ と過飽和度 $\sigma$ との関係を 示すと Fig.6のようである.汶で明らかなように過飽和 度が小さい汪ど残留率，したがって消失率 $\left(n_{0}-n_{\min }\right) / n_{0}$ が大きい。またその減少傾问はカリ明ばんのうjが硫唒銅 より著しく大きいことがおかる。

この微小粒子が娍少する原因として

i) コールターカウンターによる测定にの留差

ii) 2 次粒子小形成

の二つが考えられる。

コールターカウンターの测起上に起きる詋差はアパチ 


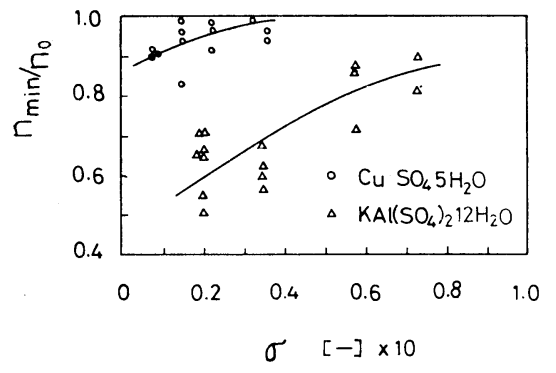

Fig. 6 Effect of relative supersaturation on remaining ratio $n_{\min } / n_{0}$

ヤー管の細孔を 2 個以上同時に通過することおよびノィ ズを計測してしまうことである．後者については前述の シールドアースによって防止することができた。また前 者についてはコールターカウンターでは同時通過補正係 数によって補正するようになっているが，この確認のた め母液をサンプリングして同温度の粒子の存在しない飽 和溶液で稀釈して計測した。その結果, サンプリングし ないで直接測定して補正した値と 5 パーセント以内で一 致することを認めた。

(ii) についてはほ液をサンプリングして顕微鏡で観 察するとともに, $0.3^{\circ} \mathrm{C}$ の低過飽和温度で 48 時間成長 させて詳細に形状を観察したが，2次粒子を形成した形 跡は認められなかった。

上記の検討により約 $50 \mu \mathrm{m}$ 以下の粒子数の減少は溶 解による消失に起因*することと思われる.

\section{$2 \cdot 2$ 粒径分布の経時変化}

代表的な経時変化を Figs. 3 と 4 に示した. 本研究 では前述のように $19 \mu \mathrm{m}$ 以下の粒子の計測をカットし たが，仮にそれらの䊀子が存在していた場合でも次の測 定時には成長して計測されるようになるので, 粒径分布 は小さい粒子の計数増のためにテーリングの傾向が表机 るはずである.ところが Fig. 3 の硫酸銅の場合では経 過時間 0.5 㧊よび 1 時間では粒径分布曲線にテーリング の傾向はまったく見られないままた Fig. 4 のカリ明ば んの場合はわずかにその傾向が見受けられるだけであ る.したがって本研究の条件では测定開始時の $19 \mu \mathrm{m}$ 以下の粒子の存在は無視し得るかまたは存在していた之 しても前節のように消失し粓径分布には影響を及ぼさな いことがわかった。

\footnotetext{
* 粓子の消失理由として火験㙅作的のものと現象的なものと二つ宩え られる. 前者で 2 次核が発生した後に母液を Fig. 2 のように急 激に加熱するので, ヒータ一の石英管表面で粒子が衝突し，溶解す ることが考えられる。しかし種々の確認実験を行ったところ、これ は消失の主因でないことが羿められた，後者では微小粒子の溶解度 は通常の溶解度より大きな值を示すことは知られているが, $50 \mu \mathrm{m}$ 以下の粒子がこれに相当するのかあるいはdehydration の不完全な 分子の集積現象が起き正規の結合エネルギーを持たない結晶が生ず る結果, 通常な溶解度を基準とした過飽和領域でも溶解現象が発生 しているのが明らかてはない。よってここでは精子の消失という站 現にとどめる.
}

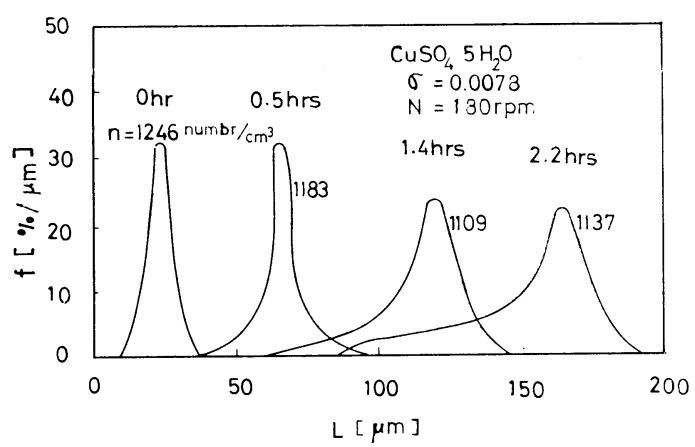

Fig. 7 Variation of number frequency distribution with elapsed time at low relative supersaturation for $\mathrm{CuSO}_{4} 5 \mathrm{H}_{2} \mathrm{O}$

Figs. 3 と 4 から粒径分布は時間の経過にしたがって, 幅が拡がる傾向が認められる。こ机は粒子群の中に, 平 均成長速度よりも早いあるいは遅い成長速度を持つ粒子 の存在を示すものである。婀図を比較して見る之特徵的 な相違点は Fig. 4 のカリ明ばんの場合では急激に成長 する粒子が存在し，粒径分布は大きい方に払がる傾向が 西るのに対して，Fig. 3 の硫酸銅の場合は成長速度の遅 い粒子の存在が，所謂テーリング現象を引き起している ことである. しかて, Fig. 3 で $\theta=3 \mathrm{hrs}$ 以前の粒径分 布曲線のテーリング現象でも成長速度の相違の他に 2 次 核の発生が原因していることも考えられるのでこの確認 を行った.すなわち 2 次核が発生しない低過飽和度で粒 径分布の経時变化を測定した．Fig. 7 はこの結果を示 し, 図から 2 次核が発生しない(粒子密度が変らない) 場合でも粒径分布が明らかにテーリングするようにな る.よってこの結果から Fig. 3 のテーリングは成長速 度の相違によると考えられる.

\section{$2 \cdot 32$ 次核発生と成長速度}

粒径分布の経時変化を示した Fig. 3 を見るこ 4 時間 後の粒子密度が急に増加している.こ机は 2 次核の発生 によるためで，図に見るように $100 \mu \mathrm{m}$ 以下の粘子の増 加が著しい、いま粒子群の平均径 $L$ を

$$
L=\frac{\Sigma n_{L} L}{\Sigma n_{L}}
$$

で表し, 成長量 $\Delta L$ と経過時間 $\theta$ との関係を求める之 Fig. 8 のようになる. 四では硫酸銅で過飽和度 $\sigma$ が 0.0078 の場合以外は初期段階を除いて，直線性が成立しないこ とがわかる。

図中の曲線の傾斜が成長速度を表すので，図から粘子 が大きくなると成長速度が小さくなるといら結果が得ら れるが，これは多量の微小粒子の発生による見掛けの值 であり，個々の粒子の真の成長速度を表すものでなくあ くまでこれは見掛け上の結果であることに注意する必要 がある.

晶析操作で粒径分布から成長速度を求めるに際して, 


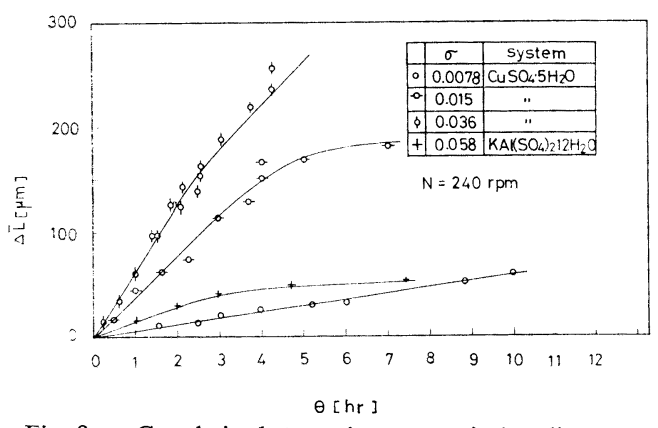

Fig. 8 Correlation between increase equivalent diameter $\Delta L$ and elapsed time $\theta$

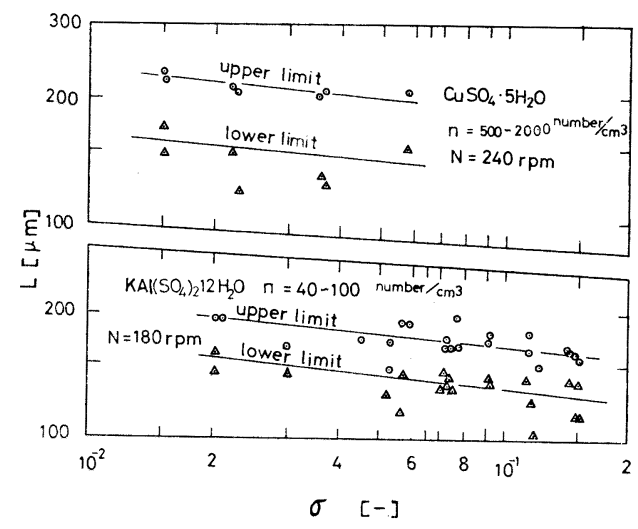

Fig. 9 Correlation between $L$ and $\sigma$

2 次核の発生があり，しかもその発生速度が変動してい る場合はこの事実に留意する必要があると思われる。

\section{$2 \cdot 42$ 次核発生のため最小粒径}

前記したように経過時間による粒子密度の変化を検討 すると，あるところで粒子密度が急激に増加するところ がある.ここで 2 次核の発生が行われていると考えられ るが，発生時の前後に和ける粒子の挙動を，その粒子群 に存在する最大径の粒子に着目して検討すると豊合 ${ }^{4)} ら$ が指摘するように，2 次核発生のための最小粒径 $L_{\mathrm{min}}$ の存在が認められる.

すなわち Fig. 3 で $\theta$ が 3 時間のとさは 2 次核は未発 生，4時間のときは既発生とし，それぞれの測定時の粒 子群に存在する最大径を求め, 前者を下限, 後者を上限 とした。

Fig. 9 は攪拌速度を一定にし上記のようにして求め た，最大径の上限下限に対する種々の粒子密度における 過飽和度のの影響を検討したもものであるが，粒子密度の 影響は本実験範囲内でほとんど認められず,わずかに過 飽和度に対して

$$
L \propto \sigma^{-0.1}
$$

の相関関係があることがわかった。

図で本研究の, 上下限值がはたして 2 次核発生時の最 大径の真の值を捉えているか否か疑問の残るところであ る.すなわち下限值でも既に発生していて，それが 19

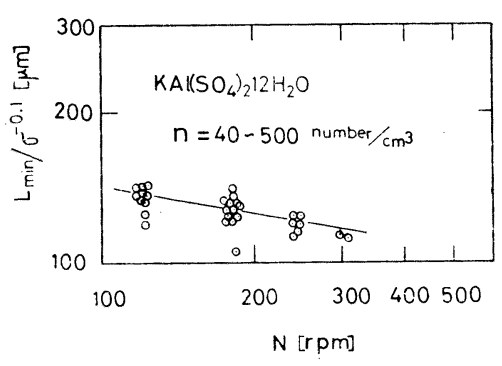

Fig. 10 Effect of impeller speed $N$ on minimum equivalent diameter for secondary nucleation

$\mu \mathrm{m}$ 以下のであったため計測されずに未発生と認定され た場合や上限值とされたものの中にも，その測定時以前 で発生していた場合が考学られる。したがって Fig. 9 はこの誤差が当然含まれる結果である。本研究では 2 次 核が発生する時の粒子群中に存在する最大径に着目して いるので, 確実に 2 次核が発生している大きさすなわち 上限値を規準にとり，これを 2 次核発生のための最小粒 径 $L_{\min }$ と定め実験值を整理した．カリ明ばんの場合の 結果を Fig. 10 に示す. 図では Fig. 9 の結果を利用し て㩭拌速度との相関関係を検討した．図からカリ明ばん の場合は粒子密度 $40 \sim 500$ 個 $/ \mathrm{cm}^{3}$ の筙囲で次の上うな 相関が得られた。

$$
L_{\mathrm{m} 1 \mathrm{n}} \propto \sigma^{-0.1} N^{-0.18}
$$

\section{3. 考察}

Figs. 3 と 4 から発生した 2 次核はその成長過程で 50 $\mu \mathrm{m}$ 以下で消失現象があることが認められた。したがっ $\tau 19 \mu \mathrm{m}$ 以下の微小粒子です当然この現象が起きるこ とが考兄られる，発生する2 次核種の大きさは Garside $ら^{1)}$ の指摘のよらに数 $\mu \mathrm{m}$ 以下と考えられるが，Fig. 6 に示したよらに，発生した 2 次核種の微小体はすべて 結晶に成長するものではなく，2 次核になり結晶に成長 するまでにかなりの部分が消失してしまう。本研究で得 たこの知見は 2 次核発生機構の究明に有益な示唆を与兄 るものと思われる。

すなわち従来から 2 次核の発生速度の定量的評価が行 われ，豊倉ら ${ }^{5}$ は過飽和度が発生速度に相関があるとい ら実験結果を得ている。この理論的背景としては Larson ${ }^{2)}$ らの説がある. Larson らは，種晶が外部から の機械的刺激によって, 結晶の一部が 2 次核種として周 囲に放散される現象が 2 次核の発生機構であるとし，そ の発生速度は破損した結晶がもとの形に復す速度が発生 速度を支配するといら説を提案している．たしかに久 損部分がある結晶では, その部分の成長は他の部分の成 長より著しく速いことを, 著者らも $\mathrm{mCNB}$ の結晶で確 認している．したがって形の修復速度が過飽和度に鋭敏 に影響するので，発生速度が過飽和度汇相関するという 
考え方も一応首肯できる.

しかし，この説では過飽和度が小さいとき 2 次核が発 生しないといら事実を説明することはできない。これに 対して微小粒子の消失現象を考兄ると矛盾なく説明する ことが可能である.すなわち結晶粒子に加兄られる機械 的刺激や流体摩擦によるせん断力などで結晶表面から供 給される 2 次核種の供給速度が仮に一定であったとして も，その成長中で消失するものがあり，その消失する割 合は Fig. 6 のように過飽和度に関係するので過飽和度が 小さくなると消失速度が供給速度に近くなり, ある過飽 和度以下では見掛け上 2 次核が発生しなくなると考兄ら れる.な抗この消失速度は系によって異なると思われる。

\section{結語}

硫酸銅 5 水塩およびカリ明ばん 12 水塩の親結晶から 2 次核を一定量発生させ, これを種々の条件で成長させて, 粒子密度と粒径分布の経時変化をコールターカウンター によって追跡し, 次の結果を得た。

1）発生した 2 次核粒子には $50 \mu \mathrm{m}$ 以下で消失する ものがあり，消失しないで残留する割合は過飽和度に関 係し, 系によっても異なる。

2) 発生した 2 次核粒子のらち, カリ明ばん 12 水塩で は異常に早く成長する粒子が存在する一方, 硫酸銅 5 水 塩では逆に遅い粒子があることが認められた。この現象 によって粒径分布の幅が拡がることがわかった。
3） 2 次核発生の最小粒径が存在し, これは過飽和度 と㨨挥速度にわずかに相関することが認められた。

\section{Nomenclature}

$$
\begin{array}{llr}
f & =\text { number frequency distribution } & {[-]} \\
L & =\text { equivalent diameter of particle } & {[\mu \mathrm{m}]} \\
L & =\text { mean equivalent diameter of particle } & {[\mu \mathrm{m}]} \\
L_{\mathrm{min}}= & \text { minimum diameter for birh of } \\
& \text { secondary nuclei } & \\
\Delta L & =\text { increase in equivalent diameter } & {[\mu \mathrm{m}]} \\
n & =\text { population density } & {[\mu \mathrm{m}]} \\
n_{L} & =\text { number of particles of } L & {\left[\text { [number } / \mathrm{cm}^{3}\right]} \\
N & =\text { impeller speed } & {[-]} \\
\theta & =\text { elapsed time } & {[\mathrm{rpm}]} \\
\langle\text { subscript }\rangle & \\
0 & =\text { value at } \theta=0 & \\
\text { min } & =\text { minimum value }
\end{array}
$$

\section{Literature cited}

1) Rusli, I. T., M. A. Larson and J. Garside: AIChE Symp. Ser., no. 193, 76, 52 (1980)

2) Larson, M. A. and L. L. Bendig: ibid, no. 153, 72 (1976)

3) Toyokura, K. and S. Hirasawa: Kagaku Kögaku, 40, 463 (1976)

4) Toyokura, K., J. Mogi and S. Hirasawa: J. Chem. Eng. Japan, 10, 35 (1977)

5) Toyokura, K., K. Sato, M. Uchiyama and K. Tawa: Kagaku Kogaku Ronbunshu, 6, 602 (1980)

(1981 年 5 月 9 日受理; 化学工学協会第 10 回秋季大会 (名 古屋, 1976 年 10 月) にて一部発表)

\title{
Occurrence and Growth of Secondary Nuclei
}

\author{
Yoshiharu Murata, Hiroshi Yamakawa, Yasunobu Kawakami, \\ Shigeru Okumoto and Takayuki Imai \\ Dept. of Chem. Eng., Tokyo Univ. of Agri. and Tech., Koganei 184
}

Secondary nuclei were generated by a parent crystal suspended in an agitated solution of $\mathrm{CuSO}_{4} 5 \mathrm{H}_{2} \mathrm{O}$ and $\mathrm{KAl}\left(\mathrm{SO}_{4}\right)_{2} 12 \mathrm{H}_{2} \mathrm{O}$, and the changes of population density and number frequency distribution with elapsed time were observed by Coulter Counter. The following results were obtained.

1) In a supersaturated solution, a decrease of population density of generated nuclei was observed at the beginning of elapsed time. The decreasing rate of particles was recognized to depend on the relative supersaturation.

2) Shape of the cumulative curve for both systems changed with elapsed time. The change for $\mathrm{CuSO}_{4} 5 \mathrm{H}_{2} \mathrm{O}$ depends on the presence of particles which have a lower growth rate than average. By contrast, the change for $\mathrm{KAl}\left(\mathrm{SO}_{4}\right)_{2} 12 \mathrm{H}_{2} \mathrm{O}$ depends on the presence of particles which have a faster growth rate.

3) Minimum particle size for the birth of secondary nuclei was confirmed 